\title{
ELEKTRONISK OVERVÅGNING I MARIN AMT, CALIFORNIEN
}

\section{Af Kirsten Sørensen}

\section{Indledning}

I august 1988 startede Marin Amt i Californien et alternativt program for personer, der er dømt i amtet for forholdsvis mindre lovovertrædelser. Den dømte prøveløslades til hjemmet på vilkår om elektronisk overvågning, således at afsoning i arresthus helt eller delvis undgås.

Programmet udspringer i opfattelsen af, at afsoning af kortere straffe kun har et element af straf og ikke er effektiv i relation til rehabilitering og forebyggelse af kriminalitet. I Marin Amt fandt man endvidere, at behandling f.eks. mod misbrug af alkohol og/eller narkotika virker mere effektivt uden for end i arresthusene. Endelig var omkostningerne ved afsoning i arresthusene blevet en alvorlig økonomisk byrde for borgerne i amtet.

\section{En kort beskrivelse af det alternative program}

I modsætning til flere amter i Californien har Marin Amt i en årrække haft et prøveløsladelsesprogram, hvilket blot vil sige, at en domfældt, der afsoner, har mulighed for at ansøge om prøveløsladelse på omtrent samme vilkår, som vi kender det i Danmark.

Det alternative program, som startede den 1. august 1988, er en del af dette prøveløsladelsesprogram, som herved blev udvidet til også at omfatte prøveløsladelse til afsoning i hjemmet med vilkår om elektronisk overvågning.

Prøveløsladelsesprogrammet administreres af Marin Amts kriminalforsorg for betingede dømte og prøveløsladte.

Afsoning i hjemmet på vilkår af elektronisk overvågning er et alternativ til almindelig afsoning. Den tilbydes egnede personer, der har begået lovovertrædelser i amtet, og som er dømt til at afsone en straf i et af amtets arresthuse. I stedet for at afsone kan den dømte søge om at blive prøveløsladt bl.a. på vilkår om elektronisk overvågning.

Vilkåret kan fastsættes for en del eller for hele prøveløsladelsesperioden.

Programmet, der i starten omfattede 25 personer under elektronisk overvågning, blev 1. juni 1989 udvidet til 35 personer og den 1. august 1990 igen udvidet til at omfatte 70 personer.

Det alternative program supplerer det allerede eksisterende frigangsprogram i amtet. Efter dette program kan personer, der er dømt til at afsone mindst 20 dage i arresthus, efter sheriffens bestemmelse få tilladelse til frigang til arbejde eller uddannelse. 
De alternative programmer reguleres af de regler og bestemmelser, der er fastsat af amtets prøveløsladelsesnævn med hjemmel i den californiske straffelov.

ECLECTIC COMMUNICATIONS, Inc. (ECI), som er det private firma, der står for den tekniske del af programmet, beskriver elektronisk overvågning således:

Elektronisk overvågning kræver et plastikbånd med en elektrode (en sender), som fastgøres om personens ankel. Senderen afgiver et signal, som opfanges af et modul, der er tilkoblet telefonen i hjemmet. Dette modul kommunikerer med en central computer via telefonnettet.

Computeren vil sørge for et løbende print af, hvornår personen går ind og ud af sit hjem og vil med jævne mellemrum foretage opkald til telefonen for at kontrollere, om personen er hjemme. Computeren registrerer enhver uorden i systemet - herunder forsøg på at ændre elektronikken, strømafbrydelser og telefonforstyrrelser. Alle deltagerne i programmet har tilladelse til at gå på arbejde, til behandling, til relevante møder og får tilstrækkelig tid til indkøb m.v.

De perioder, en person har tilladelse til at være væk fra hjemmet, bestemmes af kriminalforsorgen og indtastes i den centrale computer, som overvåger, at skemaet overholdes.

\section{Oplysninger om Marin Amt og årsagen til, at programmet blev ivaerksat}

Marin Amt udgør 859,2 kvadratkilometer og har 230.000 indbyggere. Amtet strækker sig fra Golden Gate broen i syd til Sonoma Amt i nord og er på øst- og vestsiden afgrænset af henholdsvis San Francisco bugten og Stillehavet.

Før Golden Gate broen blev bygget i 1937, var amtet et roligt landbrugs- og fiskeridistrikt, der kun var forbundet med San Francisco med en færge. Åbningen af broen forandrede amtet, som hurtigt blev en del af storbyen. Befolkningstilvæksten steg kraftigt og dermed fik amtet pludselig en masse af de problemer, der er karakteristiske for storbyer. Marin Amt har således oplevet, at kriminaliteten er øget, at den bliver mere og mere voldelig, og at misbrug af alkohol og/eller narkotika ofte helt eller delvis er en medvirkende årsag til kriminaliteten. På trods af disse forhold er Marin Amt stadig et forholdsvis roligt område. Der er ikke alvorlige raceproblemer, og befolkningen er generelt bedre uddannet og har højere indkomster end gennemsnittet i de omkringliggende områder. Der er ikke særlig mange narkotikaghettoer, og selv om der er problemer, er de ikke af så alvorlig art som f.eks. i Oakland og San Francisco.

På den ene side ønsker indbyggerne i amtet, at myndighederne beskytter dem mod kriminalitet, men på den anden side ønsker de ikke at bruge flere penge end højst nødvendigt på kriminalitetsbekæmpelse.

1 begyndelsen af 1988 blev situationen i amtet tilspidset. Når dommeren afsiger en dom, træffer han samtidig bestemmelse i dommen om, at straffen skal udstås i et af amtets to arresthuse inden for et givent antal måneder (typisk 2-3 måneder). Herefter er det op til sheriffen at sørge for, at den dømte påbegynder strafudståelsen inden for den frist, dommeren har fastsat. Sheriffen tilsiger pågældende, som så selv møder op eller bliver anholdt. I begyndelsen af 1988 var amtets arresthuse blevet stærkt 
kritiseret for afsoningsforholdene, fordi der ofte var op til 5 indsatte i hver celle; de er på størrelse med de danske. Der var anlagt sag mod amtet med påstand om, at disse forhold var i strid med forfatningen, og dommeren havde bebudet, at amtet ville blive pålagt store bøder, hvis forholdene ikke blev bragt i orden. Sheriffen var forpligtet til at lade de dømte afsone inden for den frist, dommeren havde fastsat, og kunne han ikke det, fordi arresthusene var overfyldte, måtte han sende den dømte hjem igen med det resultatet, at straffen slet ikke skulle udstås. Der er således ikke ventelister som i Danmark, og den dømte har ikke mulighed for at søge udsættelse med strafudståelsen.

Amtets kriminalforsorg havde tidligere forsøgt at få indført afsoning i hjemmet med elektronisk overvågning, men havde måttet afstå derfra på grund af modvilje dels hos befolkningen, som mente, de dømte slap for billigt ved at afsone hjemme, og dels fra dommerne, som mente, at deres domme ville blive underkendt.

For at løse pladsproblemet, at tilgodese behovet for beskyttelse mod kriminalitet, at straffe for begåede forbrydelser og at forebygge ny kriminalitet opnåede man $\mathrm{i}$ amtet enighed om at bygge et nyt arresthus og at starte programmet med elektronisk overvågning. På grund af kritikken af, at domstolene idømte for milde straffe, blev programmet lagt i kontoret for betingede dømte og prøveløsladtes regi, således at det blev en del af prøveløsladelsesprogrammet i stedet for en straf, domstolene kunne idømme.

\section{De retshåndhoevende myndigheder i Marin Amt}

Kriminalforsorgen for betingede dømte og prøveløsladte udgør sammen med politienhederne i de forskellige byer, statsadvokaten i amtet, de statslige domstole i amtet, sheriffen og prøveløsladelsesnævnet en vigtig del af de retshåndhævende myndigheder. De arbejder tæt sammen.

Sheriffen administrerer de tre arresthuse i amtet, sørger for, at de dømte udstår straffene i overensstemmelse med dommen og afgør, om en indsat $i$ arresthus kan få tilladelse til frigang.

Prøveløsladelsesnævnet er ansvarlig for prøveløsladelsesprogrammet. Nævnet består af sheriffen, som er formand, chefen for kriminalforsorgen og en borger, der er udpeget af den øverste dommer ved landsretten i amtet.

Nævnet udfærdiger alle de generelle regler og bestemmelser om prøveløsladelse. Nævnet afgør endvidere, om en indsat skal prøveløslades, fastsætter vilkårene og eventuelle sanktioner ved vilkårsovertrædelse. Forinden nævnet træffer afgøreise om prøveløsladelse, skal den dommer, der har pådømt sagen, høres, og nævnet skal lægge afgørende vægt på denne udtalelse.

I den periode den dømte er prøveløsladt, er pågældende undergivet nævnets kompetence og skal overholde de fastsatte vilkår. Nævnet kan på ethvert tidspunkt træffe beslutning om genindsættelse, hvis vilkårene overtrædes. Nævnet mødes en gang 
ugentligt, og dets afgørelser i de konkrete sager er endelige og kan ikke påklages til nogen anden instans.

Kriminalforsorgen for betingede dømte og prøveløsladte administrerer prøveløsladelsesprogrammet efter de regler og bestemmelser, der er fastsat af prøveløsladelsesnævnet, forbereder sagerne til nævnets møder og håndhæver de afgørelser, nævnet har truffet. Prøveløsladelsesnævnet har endvidere bemyndiget kriminalforsorgen til at træffe visse afgørelser i relation til prøveløsladelse.

\section{Betingelserne for prøveløsladelse}

Der vil typisk ske prøveløsladelse, når den dømte har udstået halvdelen af straffen, og prøvetiden vil normalt løbe indtil det tidspunkt, hvor den prøveløsladte ville have udstået $2 / 3$ af straffen, men den kan udstrækkes i op til 2 år fra strafudståelsen blev påbegyndt.

Ifølge de regler, der er fastsat af prøveløsladelsesnævnet, skal følgende betingelser være opfyldt, for at en person kan prøveløslades:

1. den idømte straf skal være på 60 dage eller derover,

2. mindst halvdelen af straffen skal være udstået den dag, hvor nævnet behandler ansøgningen om prøveløsladelse. Ansøgeren skal være til stede ved mødet,

3. ansøgeren må ikke udstå en straf idømt for kriminalitet begået under afsoningen,

4. der må ikke være verserende sager,

5. ansøgeren skal have opnået mindst 7 point på et særligt skema, hvor egnethed og recidivrisiko vurderes, og

6. amtets landsret må ikke have taget stilling til spørgsmålet ved domsafsigelsen.

En person, der ikke opfylder betingelserne for prøveløsladelse, kan alligevel søge kriminalforsorgen om at blive prøveløsladt, såfremt der fremskaffes tilstrækkelig dokumentation for, at afsoningen er uforholdsmæssig belastende (normalt kun i sygdomstilfælde hos personen selv eller den helt nære familie). En tilsynsførende i kriminalforsorgen gennemgår ansøgningen og skal skriftligt inden 10 dage meddele ansøgeren, om den kan behandles af nævnet på det foreliggende grundlag og $\mathrm{i}$ bekræftende fald hvornår.

Alle, der ansøger om prøveløsladelse, skal personligt give møde i nævnet, medmindre de prøveløslades administrativt, d.v.s. til varetægt eller behandlingsinstitution, hvor opholdet vil strække sig ud over datoen for endt straf.

\section{Betingelser for prøveløsladelse til hjemmet på vilkår af elektronisk overvågning}

Hovedparten af de ansøgere, der er under elektronisk overvågning, undgår helt at afsone straffen, idet de - i modsætning til de, der prøveløslades på almindelige vilkår - typisk vil blive prøveløsladt på vilkår af elektronisk overvågning den dag, de ellers skulle have påbegyndt afsoningen $\mathrm{i}$ arresthus.

En ansøger skal opfylde både nogle objektive og subjektive kriterier for at blive prøveløsladt til hjemmet på vilkår af elektronisk overvågning. 
De objektive betingelser er følgende:

1. Den idømte straf skal være på 91 dage eller derover. Grænsen på 91 dage har dels sammenhæng med, at personer, der er idømt kortere straffe, har mulighed for samfundstjeneste eller frigang fra arresthus og dels, at det er for dyrt at tilslutte det elektroniske udstyr for kortere tid end 45 dage.

2. Ansøgeren må have fast bopæl med telefon i det nordlige/centrale Bay Area.

3. Ansøgeren skal opnå 7 point på det skema, hvor egnethed og recidivrisiko vurderes. Skemaet har til formål at frasortere dem, der slet ikke er egnede til prøveløsladelse. Skemaet vil automatisk udelukke dem, der ikke har en stabil baggrund i relation til bolig og arbejde, og dem, der ikke har nogle konkrete planer for fremtiden om at blive en bedre borger.

4. Ansøgeren skal have fast arbejde, være selvstændig erhvervsdrivende eller pensioneret.

Et af formålene med det alternative program er bl.a. at sikre, at den dømte kan bevare sit job og derved undgå økonomisk tab herunder tab af sygeforsikring fra arbejdsgiveren, tab af kundekreds mv. For at sikre en ligeartet behandling har også pensionerede mulighed for at komme ind under programmet.

5. Hvis ansøgeren tidligere er dømt for overtrædelse af straffeloven, må lovovertrædelserne ikke reflektere et udpræget voldsmønster eller et liv i kriminalitet. I Marin Amt er det ikke kun førstegangsdømte, der vil have mulighed for prøveløsladelse (som i nogle andre amter). Prøveløsladelsesnævnet går 7 år tilbage og baserer sin vurdering på de faktiske oplysninger om kriminaliteten.

6. Hvis ansøgeren har et misbrug af f.eks. alkohol og/eller narkotika, eller rusmidler indgår som en del af årsagen til kriminaliteteten, må ansøgeren indvillige i at give møde hos en specialist, som vurderer motivationen for at modtage hjælp til bearbejdning af problemerne. Prøveløsladelsesnævnets vurdering baseres herefter på denne udtalelse.

Herudover vil ansøgere med dokumenterede alvorlige fysiske sygdomme kunne blive prøveløsladt på vilkår om elektronisk overvågning, selv om ikke alle ovennævnte betingelser er opfyldt.

For så vidt angår de subjektive betingelser skal ansøgeren acceptere at have begået noget kriminelt, skal erkende et evt. alkohol og/eller narkotikaproblem og skal være villig til at deltage i den nødvendige behandling mod misbruget.

Om de subjektive betingelse er opfyldt afgøres af prøveløsladelsesnævnet, som træffer afgørelsen ud fra de faktiske oplysninger om ansøgerens aktuelle forhold, som ansøgeren, naboer, venner mv. fremstiller dem på mødet med nævnet. Nævnet lægger afgørende vægt på, om ansøgeren efter den begåede kriminalitet er blevet en lovlydig samfundsborger, der vil forbedre sig og angrer det skete.

Hvis ansøgeren opfylder både de objektive og de subjektive kriterier for prøveløsladelse, vil prøveløsladelsesnævnet fastsætte vilkårene for løsladelsen. 
Vilkårene, der fastscettes i forbindelse med afsoning i hjemmet under elektronisk overvågning og perioden under overvågning

De vilkår, prøveløsladelsesnævnet kan fastsætte for almindelig prøveløsladelse, svarer til dem, der kan fastsættes i Danmark. Der vil altid blive fastsat vilkår om straffrit liv og tilsyn. Disse vilkår vil også altid blive fastsat for prøveløsladelse til elektronisk overvågning. Herudover vil der typisk blive fastsat vilkår om, at den prøveløsladte skal afholde sig fra indtagelse af alkohol og/eller narkotiske stoffer og give møde i Anonyme Alkoholikere og/eller Anonyme Narkomaner og/eller Anonyme Spillere. Som altovervejende hovedregel vil den prøveløsladte skulle give møde i ovennævnte foreninger op til en gang dagligt $\mathrm{i}$ den periode, den pågældende er under elektronisk overvågning.

Herudover vil der ofte blive fastsat vilkår om, at den prøveløsladte undergiver sig psykiatrisk/psykologisk behandling.

Endelig har prøveløsladelsesnævnet udfærdiget nedennævnte to kontrakter, som ansøgeren altid skal underskrive for at blive løsladt på prøve på vilkår om elektronisk overvågning:

\section{"A. Vilkår for afsoning $i$ hjemmet:}

1. Prøveløsladelse til afsoning i hjemmet tillades fra dag til dag, for at du kan gå på arbejde eller benytte afsoningen til formål, der i forvejen er godkendt af din tilsynsførende.

Enhver brug af tid på andet, end hvad der er godkendt af din tilsynsførende, er en overtrædelse af denne aftale.

2. Du skal være hjemme på alle de tidspunkter, hvor du ikke er på arbejde eller på indkøb i de tre timer, som i forvejen er godkendt af din tilsynsførende. Du skal være til at træffe ved telefonen hele tiden og må til enhver tid forvente besøg af din tilsynsførende i dit hjem eller på arbejde.

3. Hvis du af en eller anden årsag ikke kan forblive på dit arbejde i hele arbejdstiden, skal du straks tage hjem og omgående give besked til din tilsynsførende.

4. Du må ikke skifte job uden forudgående godkendelse fra din tilsynsførende.

5. Under ansættelsesforholdet skal du være dækket af din arbejdsgivers forsikring.

6. Hvis du bliver syg eller kommer til skade, skal du underrette din tilsynsførende, før du forlader lægen eller skadestuen. Marin Amt er ikke ansvarlig for betalingen for lægelig behandling.

Enhver pludselig opstået afvigelse fra det fastlagte skema må bekræftes ved skriftlig dokumentation.

7. Du skal vende hjem til det fastsatte tidspunkt. Hvis du i et nødstilfælde ikke kan komme hjem til tiden, skal du ringe til din tilsynsførende og fortælle årsagen til forsinkelsen og hvilket tidspunkt, du forventer at være hjemme.

8. Ændringer i det fastlagte skema skal godkendes en uge i forvejen af din tilsynsførende.

9. Din arbejdsplads vil blive kontaktet af din tilsynsførende m.h.p. bekræftelse af ansættelsesforholdet og kontrol af, at du møder på arbejde. Din arbejdsgiver må være villig til at samarbejde med din tilsynsførende og oplyse, om der er problemer på arbejdspladsen. Såfremt der sker overtrædelse af dette vilkår, vil prøveløsladelsen blive suspenderet. 
Den californiske straffelov kræver, at din arbejdsgiver underrettes om kriminalitetens art, såfremt dette skønnes relevant for ansættelsesforholdet.

Hvis du mister dit arbejde, uanset årsagen hertil, vil du ikke længere kunne blive hjemme, men vil blive indsat $\mathrm{i}$ arresthus enten midlertidigt eller for hele den resterende straffetid.

10. Du skal benytte offentlige transportmidler til og fra arbejde, din egen bil (hvis du har tilladelse til at køre) eller anden transport, der i forvejen er godkendt af din tilsynsførende. Du må ikke stoppe.

11. Du må ikke have kontakt med andre prøveløsladte, med mindre dette specielt er godkendt af din tilsynsførende.

12. Du skal betale 70 dollars om ugen, eller 10 dollars om dagen for at afsone $i$ hjemmet under elektronisk overvågning. Betaling skal ske forud til din tilsynsførende.

Hvis du undlader at betale, vil din tilsynsførende suspendere prøveløsladelsen, og der vil blive fastsat et møde i prøveløsladelsesnævnet.

Du vil ikke få udbetalt allerede betalte beløb, såfremt du indsættes i arresthus til udståelse af straffen.

13. Betaling kan kun finde sted med bankchecks udstedt til Marin Amt. Kontant betaling eller personlige checks accepteres ikke.

14. Hvis du afsoner i hjemmet og overtræder vilkårene, kan prøveløsladelsesnævnet beslutte, at du skal indsættes i arresthus til udståelse af den idømte straf uden fradrag for den tid, du har været prøveløsladt på vilkår om elektronisk overvågning.«

»B. Yderligere vilkår:

1. Din deltagelse i dette program vil blive overvåget via et stødsikkert ankelbånd, som du indvilger $\mathrm{i}$ at bære hele døgnet igennem hele den periode, du er prøveløsladt under dette program.

Din tilstedeværelse i hjemmet vil blive overvåget via en central computer i San Francisco.

2. Det er nødvendigt, at din tilsynsførende får adgang til at tilslutte modulet til din telefon, $\mathrm{og}$ du skal derfor tillade din tilsynsførende adgang til din bopæl for at installere, vedligeholde og kontrollere udstyret.

Alle de personer, der har bopæl sammen med dig, skal underrettes om din deltagelse i programmet og skal have underretning om det tekniske udstyr og indvillige i at støtte dig under afsoningsperioden.

3. Din telefonservice må ikke includere videresendelse af telefonopkald til dig til andet telefonnummer. Du skal acceptere at lægge røret på under en telefonsamtale, såfremt du hører et klik i telefonen. Dette betyder, at en stemmetest vil finde sted.

Hvis du ikke lægger røret på, vil det blive betragtet som en vilkårsovertrædelse.

Som følge af din deltagelse i programmet, vil din telefonregning blive større, idet du selv skal betale for opkaldene fra den centrale computer i San Francisco.

Du skal selv betale for alt ekstraudstyr, der er nødvendigt, for at det elektroniske udstyr kan fungere.

Hver måned skal du fremvise din telefonregning, for at det kan kontrolleres, om opringninger til dig videresendes til et andet telefonnummer.

Afmelding eller lukning af telefon betragtes som vilkårsovertrædelse og vil medføre, at du vil blive indsat $\mathrm{i}$ arresthus til udståelse af hele straffen. 
4. Såfremt du ikke svarer på telefonopkald på de tidspunkter, hvor du skal være hjemme, formodes det, at du har overtrådt vilkårene.

Computerens print betragtes som bevis herfor.

5. Det tekniske udstyr tilhører ECI, Inc. Du er ansvarlig for udstyret. Hvis noget af udstyret mistes eller går i stykker, skal du betale for genanskaffelse eller reparation.

Hvis udstyret stjæles på din foranledning, kan du straffes med bøde eller fængsel.

6. Misbrug af det elektroniske udstyr medfører indsættelse i arresthus til udståelse af hele den idømte straf."

Hvis den dømte underskriver ovennævnte to kontrakter og oplyser at ville overholde de vilkår, der i øvrigt fastsættes, vil prøveløsladelsesnævnet fastsætte en dato for prøveløsladelsens start.

Herefter overgår sagen til den tilsynsførende, som tager hjem til den prøveløsladte, installerer det elektroniske udstyr og viser, hvor grænsen for bevægelsesfriheden går. Den tilsynsførende har endvidere en mere grundig samtale med den prøveløsladte og dennes familie om de problemer, der kunne tænkes at opstå, og der fastlægges det skema, som skal indtastes i computeren, så hjemmetid og udetid er fastlagt.

Et medlem af husstanden skal underskrive den sidstnævnte kontrakt og love at støtte den prøveløsladte, arbejdsgiveren underrettes og skal også love at støtte den prøveløsladte og melde tilbage til kriminalforsorgen, såfremt der opstår problemer på arbejdspladsen. Den prøveløsladte kan altid få kontakt med den tilsynsførende på kontoret fra kl. 8-17 mandag til fredag. På alle andre tidspunkter er det muligt at indtelefonere en besked til en telefonsvarer. Den tilsynsførende tager på uanmeldte besøg hjemme hos den prøveløsladte, på dennes arbejde og hos ex. Anonyme Alkoholikere imellem kl. 9-22 mandag til fredag. Disse uanmeldte besøg vil finde sted i hvert fald to gange om ugen, og hver gang vil der blive forlangt urinprøver for at konstatere evt. misbrug, hvis der er fastsat vilkår om, at den prøveløsladte ikke må indtage alkohol og/eller narkotiske stoffer.

Antallet af uanmeldte besøg varierer alt efter et skøn over behovet herfor dels i relation til kontrol med, at vilkårene overholdes og dels i relation til, hvor stort et behov den prøveløsladte og dennes familie har for at tale om problemer.

Den centrale computer i San Francisco registrerer alene, hvornår den prøveløsladte kommer hjem eller forlader hjemmet. I de perioder, hvor den prøveløsladte skal være hjemme, vil computeren foretage opkald og bede den pågældende om at gentage nogle bestemte ord for at kontrollere, at det er den prøveløsladte, der svarer telefonen. En afvigelse fra denne stemmetest eller fra det fastlagte skema medfører, at computeren afgiver et signal til printeren, hvilket indberettes til den tilsynsførende.

\section{Reaktioner ved overtrcedelse af vilkårene for prøveløsladelsen}

Hvis en prøveløsladt formodes at have overtrådt vilkårene for prøveløsladelsen, har prøveløsladelsesnævnet bemyndiget lederen af kriminalforsorgen til uden yderligere 
varsel efter et konkret skøn at foranledige, at en prøveløsladt genindsættes m.h.p. fremstilling i et møde i nævnet, hvis pågældende:

»1. har overtrådt eller formodes at have overtrådt et af vilkårene i kontrakterne om afsoning i hjemmet,

2. har overtrådt vilkår om forbud mod besiddelse eller brug af alkohol og/eller euforiserende stoffer,

3. ikke undergiver sig test mod misbrug af alkohol og/eller euforiserende stoffer på anmodning herom fra den tilsynsførende,

4. har overtrådt eller formodes at have overtrådt ethvert vilkår fastsat for prøveløsladelsen, der skal beskytte samfundet eller dets medlemmer«.

Lederen af kriminalforsorgen er også bemyndiget til at suspendere prøveløsladelsen uden indsættelse i arresthus, hvis den prøveløsladte har, eller formodes at have, overtrådt et hvilket som helst vilkår for prøveløsladelsen og skal så samtidig træffe bestemmelse om, at den prøveløsladte skal give møde for prøveløsladelsesnævnet m.h.p. afgørelse af, om der er tale om en vilkårsovertrædelse.

Hvis den prøveløsladte erkender at have overtrådt et eller flere af vilkårene for prøveløsladelsen, har prøveløsladelsesnævnet bemyndiget lederen af kriminalforsorgen til at fastsætte en eller flere af følgende sanktioner:

1. advarsel,

2. ændring af de eksisterende vilkår for prøveløsladelsen eller fastsættelse af yderligere vilkår, eller

3. forlængelse af perioden for prøveløsladelsen indtil det tidspunkt hvor pågældende ville have udstået $2 / 3$ af straffen.

Hvis den prøveløsladte ønsker en af kriminalforsorgens afgørelser indbragt for prøveløsladelsesnævnet, skal pågældende, inden 2 døgn efter at afgørelsen er truffet, fremkomme med indsigelser overfor kriminalforsorgen, som så sørger for, at sagen behandles på det næste møde i nævnet. Hvis nævnet, efter en høring, finder, at et eller flere vilkår er overtrådt, kan det træffe bestemmelse om enten de samme sanktioner, som kriminalforsorgen kan fastsætte eller om indsættelse i arresthus til udståelse af hele den idømte straf uden hensyntagen til, hvor længe den pågældende har været prøveløsladt på vilkår af elektronisk overvågning.

Finder nævnet, at der ikke er tale om en vilkårsovertrædelse, tilbagekaldes suspensionen af prøveløsladelsen.

Hvis den prøveløsladte har overtrådt nogle af vilkårene og derfor skal indsættes til udståelse af straffen, sker dette øjeblikkeligt og uden hensyntagen til, at pågældende eventuelt vil miste sit arbejde. Der er således ingen mulighed for at forberede strafudståelsen eller søge udsættelse.

Hvis den prøveløsladte anholdes og varetægtsfængsles for ny lovovertrædelse, vil der blive truffet bestemmelse om, at pågældende ikke kan løslades mod kaution, før sagen har været behandlet i kriminalforsorgsnævnet. 
Nogle af de impliceredes syn på elektronisk overvågning

Prøveløsladelsesnævnet betragter elektronisk overvågning som svarende til afsoning $i$ et arresthus med frigang - altså som en straf.

»At afsone i hjemmet er ensbetydende med at sætte sig selv i fængsel og kræver en meget stærk personlig psyke og støtte fra omgivelserne. Med det alternative program håber man i amtet på at kunne støtte de lovovertrædere, der oprigtigt ønsker at overstå et fejltrin i livet og overvinde eventuelle problemer.

Programmet støtter på to måder: for det første får den dømte en chance for at fortsætte dagliglivet med deres familier, arbejde og venner, og for det andet får den dømte hjæelp til at overvinde ex. alkohol og/eller narkotikamisbrug i deres sædvanlige omgivelser, som de alligevel skulle tilbage til efter en afsoning $i$ et arresthus.

Hertil kommer, at der er bedre muligheder for behandling mod evt. problemer udenfor arresthusene«.

Generelt kan følgende oplyses om deltagerne:

De fleste prøveløslades inden afsoningen påbegyndes og undgår derfor helt at komme i arresthus.

Mere end halvdelen er dømt for overtrædelse af narkotikalovgivningen eller for spirituskørsel og har alvorlige misbrugsproblemer.

Personer, der er dømt for spirituskørsel, er alle dømt tredie gang til at afsone mindst 120 dage. Førstegangsovertrædelse for spirituskørsel straffes med en bøde og kørekortet inddrages, medmindre domfældte gennemgår et 12 timers kursus mod misbrug af alkohol.

Overtrædelse anden gang straffes med en bøde, inddragelse af kørekortet, og domfældte skal deltage i et et-årigt kursus mod misbrug af alkohol med gruppemøder og en times personlig rådgivning om ugen.

Under besøg i hjemmet støder de tilsynsførende ofte på massive familieproblemer, og det er meget tit hele familien, der skal have lagt deres tilværelse om. De tilsynsførende stiller derfor hjælp, rådgivning m.v. til rådighed for hele familien.

Når en person afsoner i hjemmet under kontrol af elektronisk overvågning uden den daglige mængde alkohol og/eller narkotika, og hele familielivet ændres i denne periode, er vold i familien en risiko. De tilsynsførende er derfor meget opmærksomme på - og specielt trænede via kurser til - at opdage tegn på problemer i familien som f.eks. fysisk eller psykisk vold og vil træde til ved samtaler og henvisninger til professionel hjælp i det omfang, det er nødvendigt.

Prøveløsladelsesnævnet betragter deltagerne i programmet som ansvarlige voksne, der selv har indflydelse på deres liv, og på grund af den grundige udvælgelse før en dømt prøveløslades på vilkår af elektronisk overvågning, kan den tilsynsførende som udgangspunkt gå ud fra, at tegn på vilkårsovertrædelse ikke er alvorlig (d.v.s. for nogens liv eller helbred). Den prøveløsladte har typisk hjem, familie, venner og 
job, som ønskes bevaret, og er klar over, at den valgte afsoningsform hjælper til at undgå personlige og økonomiske tab.

De, der har været prøveløsladt på vilkår om elektronisk overvågning, har typisk udtrykt tilfredshed med ordningen. Tilfredsheden skyldes, at de får professionel hjælp til at komme ud af alkohol og/eller narkotikamisbrug, at de kan være sammen med familien i stedet for at sidde i et arresthus, men ikke mindst, at der ikke er noget alternativ. Der er ikke mulighed for at søge udsættelse med strafudståelsen, og de fleste ville miste arbejdet og dermed sygeforsikring og evt.bolig, bil mv., hvis de skulle afsone i arresthus i en længere periode. Endelig er den allerførste forudsætning for at blive prøveløsladt på vilkår om elektronisk overvågning, at den pågældende selv ansøger om det.

Fakta om dem, der har vœeret prøveløsladt til hjemmet på vilkår af elektronisk overvågning

En foreløbig rapport fra 1. maj 1989 fra The Office of the Criminal Justice Coordinator oplyser følgende:

Fra 1. august 1988 til 1. februar 1989 er i alt 128 personer (111 mænd og 17 kvinder) fra 18 til 75 år blevet prøveløsladt af Marin Amts prøveløsladelsesnævn. Af disse 128 personer blev 74 prøveløsladt på vilkår af elektronisk overvågning, mens $54 \mathrm{blev}$ prøveløsladt på almindelige vilkår.

I relation til vurderingen af gennemførelsesprocenten definerer kriminalforsorgen for betingede dømte og prøveløsladte i Marin Amt ikke-gennemførelse af programmet således: indsættelse i arresthus til udståelse af straffen på grund af vilkårsovertrædelse, arrestation for ny kriminalitet og forlængelse af prøveløsladelsesperioden uden indsættelse $\mathrm{i}$ arresthus.

Af de 128 personer, der blev prøveløsladt, havde 113 afsluttet prøveløsladelsesperioden den 1. februar 1989. 15 personer var stadig prøveløsladt og disse er udtaget fra nedennævnte skema over hvem, der har gennemført og hvem, der ikke gennemførte programmet.

\begin{tabular}{lccl}
\hline & $\begin{array}{l}\text { elektronisk } \\
\text { overvågning }\end{array}$ & $\begin{array}{l}\text { almindelig } \\
\text { prøveløsladelse }\end{array}$ & \\
\hline Ikke gennemført & 4 & 10 & 14 \\
& $3,5 \%$ & $8,8 \%$ & $12,4 \%$ \\
Gennemført & 57 & 42 & 99 \\
& $50,4 \%$ & $37,2 \%$ & $87,6 \%$ \\
& 61 & 52 & 113 \\
& $53,9 \%$ & $46,0 \%$ & \\
\hline
\end{tabular}


Den foreløbige rapport konkluderer følgende om ovennævnte tal:

»Det fremgår af skemaet, at 14 ud af 113 prøveløsladte ikke gennemførte prøveløsladelsesperioden, mens 99 gennemførte elektronisk overvågning/almindelig prøveløsladelse. Af de, der ikke gennemførte, var 4 prøveløsladt på vilkår af elektronisk overvågning, mens 10 var prøveløsladt på almindelige vilkår. Skemaet tyder på, at de, der blev prøveløsladt på vilkår af elektronisk overvågning er mere tilbøjelige til at gennemføre prøveløsladelsesperioden end de, der afsonede i arresthus og derefter blev prøveløsladt på almindelige vilkår. Dette skyldes sandsynligvis den tekniske overvågning, som til stadighed påminder den prøveløsladte om hans deltagelse i programmet og dels den hjælp, den prøveløsladte modtager fra den tilsynsførende, Anonyme Alkoholikere mv.

En ikke-gennemførelsesprocent på 12,4 er ikke kraftigt afvigende fra det, der er erfaret fra andre lignende forsøg med prøveløsladelser.

Ikke desto mindre er procenten af ikke-gennemførelser for de prøveløsladte på vilkår af elektronisk overvågning noget mindre end $\mathrm{i}$ andre områder, hvor elektronisk overvågning benyttes. Denne mindre procent for de, der ikke gennemførte elektronisk overvågning, skyldes sandsynligvis de behandlingsmuligheder, der foreligger, det tætte tilsyn og prøveløsladelsesnævnets konsekvens m.h.t. indsættelse til udståelse af straffen i arresthus ved vilkårsovertrædelse. (Det bemærkes i den forbindelse, at årsagen til de fleste ikke-gennemførelser skyldes vilkårsovertrædelse og ikke ny kriminalitet. 6 ud af de 14 gennemførte ikke på grund af overtrædelse af vilkårene, hvilket resulterede $\mathrm{i}$, at prøveløsladelsesperioden blev forlænget).

Fordelt på straffens længde og kriminalitetens art var $28,1 \%$ af de prøveløsladte dømt for felonies (lovovertrædelser, hvor strafferammen er over 1 år) og 71,9\% for misdemeanors (lovovertrædelser, hvor strafferammen er op til 1 år, og afsoning finder sted i arresthus).

Næsten $76 \%$ af alle var dømt for spirituskørsel $(61,7 \%)$ og felony-narkotikakriminalitet $(14,1 \%)$, kørsel uden kørekort udgjorde $8,6 \%$ og felony-kriminalitet mod fast ejendom (primært indbrud) udgjorde $7 \%$. De resterende $8,6 \%$ var spredt ud over flere kriminalitetstyper.

Den gennemsnitlige idømte straf for de, der blev prøveløsladt på vilkår af elektronisk overvågning, var 206,5 dage med en mindstestraf på 90 dage og maximum på 750 dage. Den hyppigst idømte straf var på 120 dage.

Til sammenligning var den gennemsnitlige idømte straf for de, der blev prøveløsladt på almindelige vilkår 223,6 dage med en mindste straf på 60 dage og maximum på 990 dage. Også her var den hyppigst idømte straf på 120 dage«.

\section{Den foreliggende rapport konkluderer følgende:}

„Denne foreløbige rapport lader formode, at prøveløsladelse på vilkår af elektronisk overvågning i hjemmet er et positivt element $\mathrm{i}$ amtets prøveløsladelsessystem. Ikke desto mindre er det nødvendigt at studere programmet over en længerevarende periode for at få bekræftet den formodning og vurdere både elektronisk overvågning og almindelig prøveløsladelse i relation til recidiv.«

Rapporten er desværre ikke blevet fulgt op af en ny undersøgelse. 
Omkostningerne ved elektronisk overvågning

Omkostningerne ved elektronisk overvågning beror på mange forskellige ting, som varierer fra tid til anden.

De totale omkostninger omfatter bl.a. betaling til ECI Inc. for leje af udstyr, for computerens opkald til den prøveløsladte ved stemmetests, for ECI's daglige opringninger til kontoret for prøveløsladte for at indberette om vilkårsovertrædelse m.v. Marin Amt har aftalt en fast pris med ECI. Herudover omfatter omkostningerne leje i amtets administrationsbygning, elektricitet, materialer, telefon, løn til de ansatte m.v.

Derfor er det ikke muligt at opgøre omkostningerne generelt ved et sådant program, men det kan konstateres, at det for amtet koster langt mindre end afsoning $\mathrm{i}$ arresthus.

Hertil kommer, at procenten af dem, der gennemførte programmet, er højere end for de, der gennemførte en almindelig prøveløsladelse.

Hvis denne tendens viser sig at være typisk, vil der blive sparet meget, selv om nogle af de prøveløsladte vil blive indsat $i$ arresthus til udståelse af straffen på grund af vilkårsovertrædelse.

\section{Konklusion}

Det alternative program med prøveløsladelse på vilkår af elektronisk overvågning opfattes i amtet som vellykket, dels fordi kun 4 ud af 61 prøveløsladte frem til 1. februar 1989 blev indsat $\mathrm{i}$ arresthus til udståelse af straffen, og dels fordi amtet på den måde har fået etableret behandlingsmuligheder, som der ikke tidligere havde været penge til eller stemning for hos amtets borgere, som typisk ønskede straffe i stedet for behandling.

På denne baggrund har Marin Amt nu udvidet programmet fra at kunne omfatte 25 til at kunne omfatte 70 prøveløsladte på en gang.

I august 1990 oplyste kriminalforsorgen, kontoret for betingede dømte og prøveløsladte, at ordningen vil blive udvidet til at kunne omfatte flere dømte, såfremt der er behov herfor.

Adresse:

Kirsten Sørensen

Fuldmægtig

Direktoratet for Kriminalforsorgen

København 